\title{
Initial stages of laminar calcrete formation by roots: examples from the Neogene of central Spain
}

\author{
Ana M. Alonso-Zarza * \\ Departamento de Petrología y Geoquímica, Facultad CC. Geológicas, Universidad Complutense, Madrid 28040, Spain
}

\begin{abstract}
Thin carbonate laminae formed by root activity are common within Miocene detrital deposits of the Duero and Madrid basins. The laminae are about $3 \mathrm{~cm}$ thick, extending several metres laterally, and displace the original detrital sediment, which ranges in grain size from fine gravel to sandy clay. The thickness, morphology, microstructure and stable isotope compositions of the laminae indicate that they formed by the activities of roots and associated microorganisms within the soil. The laminae are similar to those commonly recognised in thick laminar calcrete profiles. Three types of laminae are recognised. Differences in the micromorphology of the laminae are explained as reflecting the different organisms involved and whether calcification occurred when the root was alive or decaying. The first type occurs in a profile at Paracuellos the Jarama, where the laminae consist of a mosaic of $20 \mu \mathrm{m}$ calcite crystals whose arrangement indicates that calcification took place in the medulla of the root and probably occurred while the plant was alive. In a second type in the Villacadima profile, laminae comprise calcified root mats whose formation indicates the interplay of roots and fungi. Calcification of the cell-walls and intracellular spaces took place in the cortices of the roots and not in the medullas as revealed by the presence of central pores in every calcified root. A third type of lamina is recognised in profiles at Viñegra de Moraña and consists of mucilaginous sheets coated by needle-fibre calcite crystals. The occurrence of associated small root casts indicates that formation of the laminae occurred while the root was decaying and was also influenced by fungal activity. These laminae occur within poorly developed soils and their formation was controlled by the relationship between sedimentation, erosion and soil formation processes. Thus, the occurrence of these laminae interbedded with detrital sediments reflects environments where sedimentation was relatively low and episodic, so after the detrital sediment input surfaces were stable and root mats were able to develop. Renewed sedimentation accounted for the death of the root mats and the development of new ones on the new surfaces. Where the sedimentation rate is lower the laminae tend to amalgamate and thicker laminar calcrete profiles form with little or no interbedded detrital sediment.
\end{abstract}

Keywords: laminar calcretes; calcified roots; carbonate laminae; paleosols; fungal activity

\section{Introduction}

Laminar calcretes have been the subject of many papers in the last two decades, but aspects on their origin are still matters of debate as shown by the

*Fax: +34-91-544-2535; E-mail: alonsoza@eucmax.sim.ucm.es work of Verrecchia et al. (1995) and the discussion and reply by, respectively, Wright et al. (1996) and Verrecchia et al. (1996). The debate is focused on the role of different organisms in the formation of laminae and in the environmental conditions that are required for the life of these organisms. In short, for some authors (Verrecchia et al., 1995) cyanobacteria 
are responsible for the formation of some calcrete laminar crusts and so the laminae must have formed at the surface in direct contact with the atmosphere. By contrast, Wright et al. (1996) considered that roots are the active agents responsible for the formation of these laminar crusts and so the laminae are formed within the soil, not at the surface (Wright et al., 1995). An additional point for discussion is that calcretes, and specifically thick laminar calcrete profiles, have been considered to be good indicators of subaerial environments as reflecting long periods of subaerial exposure and thus, relatively stable landscapes. However, it has recently been shown that thick laminar calcrete profiles are the result of multiple phases of erosion, deposition and soil formation (Fedoroff et al., 1994; Alonso-Zarza et al., 1998b), indicating their formation on landscapes less-stable than previously considered. In many cases the laminae within a laminar calcrete are so amalgamated that it is difficult to separate phases and to establish the relative timing and processes operating in their formation. In order to avoid this problem thin micritic laminae or veins isolated within detrital sediments have been selected for study. The morphologies and textures of these laminae indicate that they are similar to laminae that form the tops of thick classical calcrete profiles (Esteban and Klappa, 1983; Machette, 1985) and represent the initial stages of formation of thick laminar calcretes. They have been recognised at the base of rhizogenic calcretes under the name of strings (Wright et al., 1995) and their formation seems to be controlled by root activity; they have been referred to as calcified root-mats or rootcretes (Jones, 1992).

In this paper three examples of incipient laminar calcretes occurring as thin carbonate laminae within detrital sediments will be analysed. The laminae are isolated but connected vertically and seem to displace and corrode the detrital deposits. It is intended to demonstrate that laminar calcrete formation took place within the soil, and that the development of different laminae was controlled by the relationship between sedimentation, erosion and soil formation. In the three examples studied the microstructure of the laminae is different indicating that calcification and preservation of the root structures varied in relation to the organisms involved and the temporal relationship between calcification and root decay.

\section{Techniques and methods}

The selection of the study areas was based on previous field work and on an earlier study in the Paracuellos area (Alonso et al., 1986). The areas were chosen because of similarities in the arrangement and field characteristics of the carbonate laminae and their substrates. More than 40 thin sections were analysed under transmitted light. Most preparation followed standard procedures, but soft, mostly Viñegra samples, were prepared following the procedure described by Tate and Retallack (1995). Scanning electron microscopy was carried out on a JEOL 6400 working at $20 \mathrm{kV}$, fracture surfaces were coated with gold. The mineralogy of the samples was determined using a Philips XRD system operating at $40 \mathrm{kV}$ and $30 \mathrm{~mA}$ with monochromatic CuK radiation. Stable isotope analyses were carried out on previously powered samples that were analysed, following reaction with $100 \%$ phosphoric acid, with a SIRA mass spectrometer.

\section{Geological and palaeoenvironmental setting}

The carbonate laminae analysed in this paper occur at Viñegra de Moraña, Villacadima and Paracuellos de Jarama within Miocene deposits of the Duero and Madrid basins of central Spain (Fig. 1). These basins contain continental deposits ranging in age from Palaeogene to Pliocene and consisting of a variety of terrestrial sediments ranging from coarse gravels, sands and clays to carbonates and evaporites (Junco and Calvo, 1983; Portero and Olivé, 1983; Calvo et al., 1996; Santisteban et al., 1996). The sediments that contain the carbonate laminae are Miocene sands, fine-grained gravels, and clays deposited in alluvial fans.

The Paracuellos de Jarama area has been the subject of several studies in recent years, focusing on the north-south transition from arkosic alluvial fans to lake deposits, that takes place in less than $5 \mathrm{~km}$ (Alonso et al., 1986). The transition zone includes a belt, about $0.5 \mathrm{~km}$ wide, of carbonate paleosols, either calcretes or dolocretes (Alonso-Zarza et al., 1992), that developed on fine arkosic sands and brown clays. The arkosic beds are similar to deposits in the Viñegra de Moraña area. The alluvial fans 


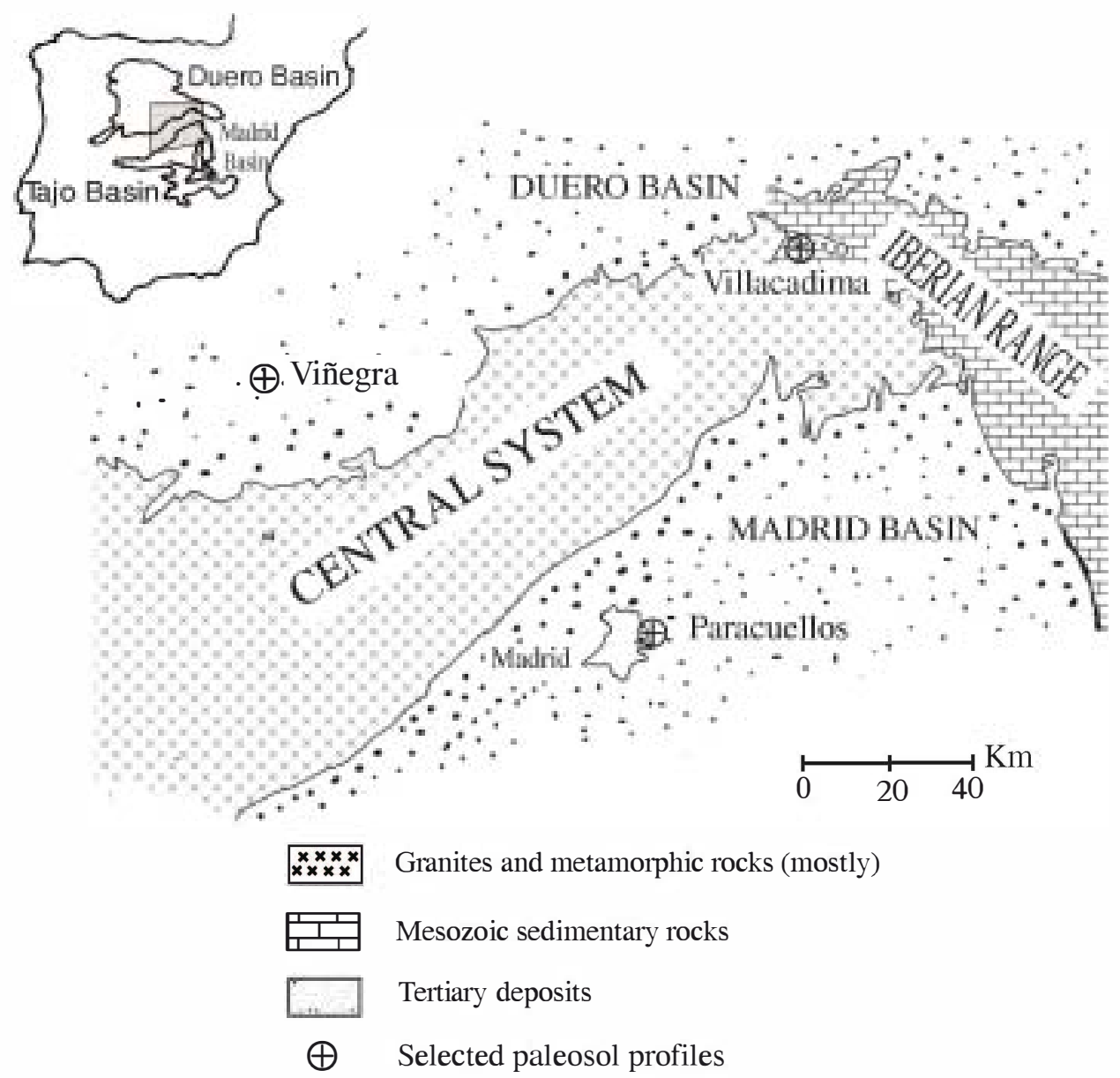

Fig. 1. Situation of the Duero and Madrid basins within the Iberian Peninsula and location of the studied profiles.

expanded southwards and were mostly fed by the granites of the Central System (Fig. 1).

The Villacadima area is somewhat different as it is located in a small depression in the Mesozoic deposits that fringe the northernmost edge of the Central System. The depression is filled with coarse gravels consisting mainly of clasts of limestones, dolostones and sandstones of the adjacent Mesozoic rocks. The gravels were deposited by small alluvial fans with distal facies of red mudstones interbedded with sandstones. Freshwater limestones are intercalated with the mudstones to the north. Well developed calcretes or dolocretes have not been recognised in this area, and the only pedogenic carbonates present are the laminae described here.
In the Viñegra de Moraña area the Neogene sediments are sourced from the granites and metamorphic rocks or the Central System. In proximal areas, large alluvial fan systems extended northwards, depositing coarse gravels with clasts up to $1 \mathrm{~m}$. The gravels grade rapidly into extensive sheet-like arkosic sands of about $2 \mathrm{~m}$ thick. The arkoses are finer grained and thinner to the north. They commonly show erosive bases with pockets containing granite and gneiss boulders up to about $20 \mathrm{~cm}$ diameter. The beds usually show repeated sequences of normal grading, that end with an upper term of finer-grained arkosic sand, silt or clay. Sorting is poor and grains are commonly angular to subangular. Feldspars are fresh and scarcely weathered. Towards 
the north and west the fine-grained arkoses and clays are intercalated with carbonates deposited in freshwater lakes (IGME, 1980). Thick calcrete-dolocrete profiles are not recognised in this area.

\section{Description of the carbonate laminae}

The laminae occur within poorly developed soil profiles (Fig. 2) and are considered to be incipient laminar calcretes. In the three areas examined the dimensions and arrangement of the laminae within the profiles are very similar, but they show a variety of detailed microfabrics (Fig. 2). A number of paleosol profiles containing carbonate laminae have been analysed. The most characteristic profile of each area will be described focusing on the microfabric of the carbonate laminae.

\subsection{Carbonate laminae in the Paracuellos de Jarama area}

In this area the carbonate laminae occur in the lower and upper parts of calcrete and/or dolocrete profiles developed in sandy clays deposited in the distal areas of arkosic alluvial fans. The mean thickness of the profiles is $1.5 \mathrm{~m}$ and they consist of three horizons (Fig. 2). The lowest contains the more distinctive laminae (Figs. 2 and 3A) and consists of brown bioturbated clay with rhizoliths. The rhizoliths are vertical and horizontal tubes about $4 \mathrm{~mm}$ wide and $4 \mathrm{~cm}$ long. The tubes are filled by micrite and microspar with, occasionally, some clay. The intermediate horizon, $0.2-0.8 \mathrm{~m}$ thick, is hard and white with a prismatic structure (Fig. 3A). It sharply overlies the clays. The prisms are up to $0.4 \mathrm{~m}$ long and average $60 \mathrm{~mm}$ in width and they consist of a dense mosaic of microspar and pseudospar with some floating detrital grains. The uppermost horizon is a platy unit (Fig. 2), $0.6 \mathrm{~m}$ thick, consisting of irregular and discontinuous centimetre-thick laminae of dense micrite with floating grains and clay aggregates disrupted by finer laminae of micrite and microspar.

In the Paracuellos de Jarama area the carbonate laminae consist of a mosaic of calcite and/or dolomite crystals. The arrangement of crystals within the laminae varies from more or less homogeneous to concentric (Fig. 3B). When the concentric pattern is present, the inner zone of lamina comprises isodiametric crystals lacking intracrystalline porosity. These are overlain by a micritic ring. In the outer zone crystals are elongated and may contain black nuclei (Fig. 3C) or a central pore (Fig. 3D,E). The crystals may be calcite or dolomite and their morphology and size do not depend on the mineralogy
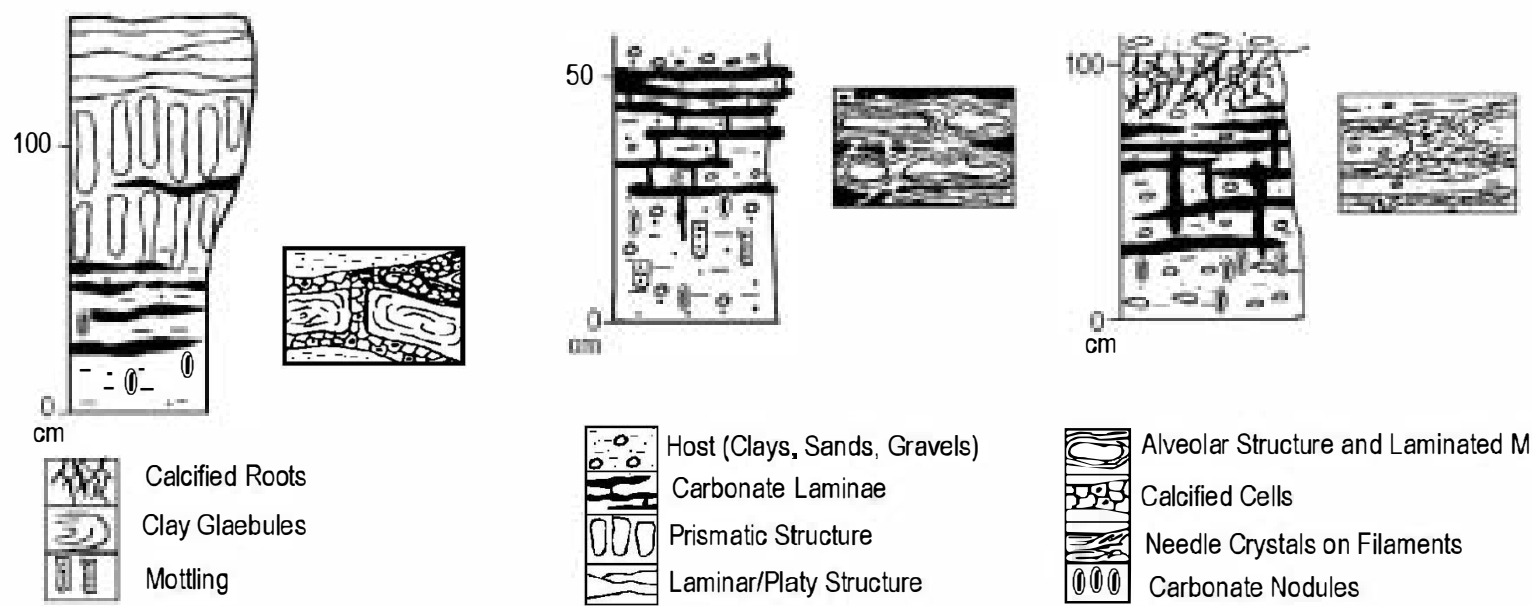

Fig. 2. Paleosol profiles of the three studied areas. The microfabric of the laminae is sketched at the right of each profile.

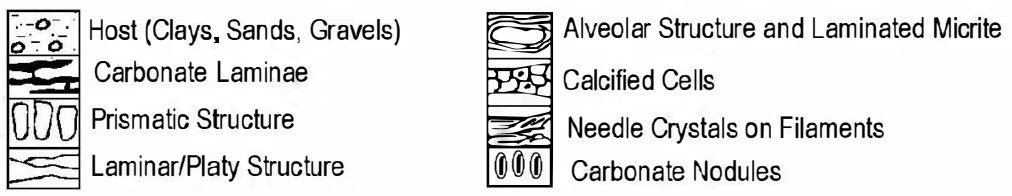



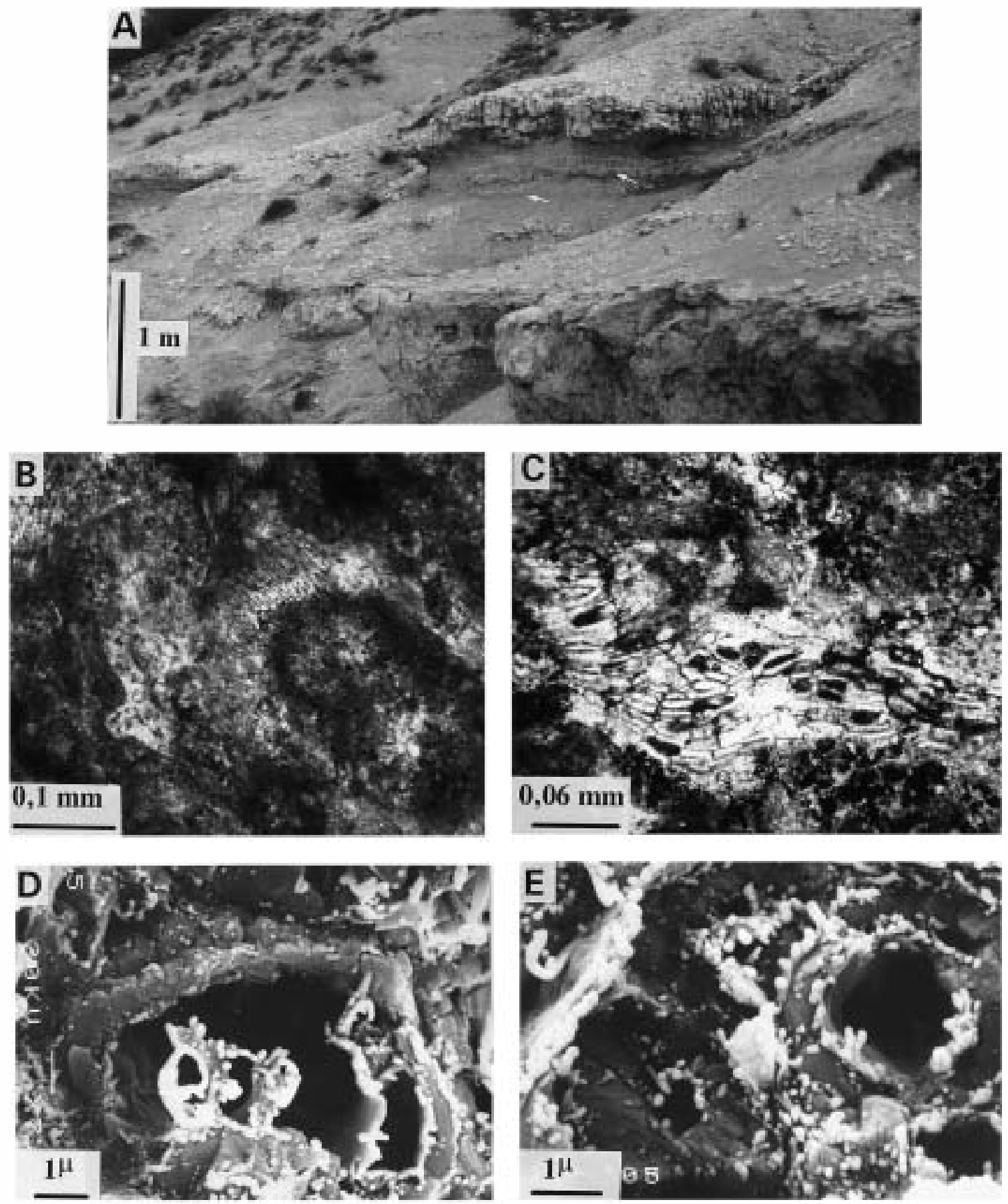

Fig. 3. Paracuellos laminae. (A) Field view of two calcrete profiles. The laminae occur in the lower horizons (arrowed) as well as in the uppermost one, but micromorphology is more clearly preserved in the lower ones. A clear prismatic horizon can be observed in the uppermost profile. The host is composed of brown bioturbated clays. (B) Microphotograph showing the concentric arrangement of crystals within the laminae. The inner part is composed of isodiametric crystals, the darker part, composed of micrite, has been interpreted as the endodermis of the root. The extemal areas are formed by more elongated crystals in which only the cell-walls are calcified. (C) Photomicrograph of the crystals (calcified-cells) in the cortex of the calcified root. (D) SEM image. View of the crystals showing a central pore that corresponds to the protoplast of the cell, only the cell wall is calcified. (E) SEM view of several crystals showing biotic structures in their porosity. 
but on the position they occupy in the lamina. Crystals show a uniform extinction and vary from 15 to $35 \mathrm{~lm}$ in diameter. They may be rounded or more or less polygonal. Microbial structures are common around the crystals and in the porosity (Fig. 3D,E).

\subsection{Carbonate laminae in the Villacadima area}

In the Villacadima area the carbonate laminae developed within the distal facies of alluvial fans sourced from adjacent Mesozoic terrains. Laminae are intercalated in red mudstones that include sheets of sandstone and gravel of centimetre thickness. These detrital deposits consist mostly of limestone and sandstone clasts. The laminae occur in profiles about $50 \mathrm{~cm}$ thick, whose bases and tops are transitional with the host detrital sediments (Fig. 2). The base of the profile includes an irregular and discontinuous horizon of dispersed vertical carbonate nodules and green mottling. Individual laminae vary from a few $\mathrm{mm}$ to $5 \mathrm{~cm}$ and their contact with the detrital sediments is very sharp but irregular at both the base and top (Fig. 4A). In general, the horizon containing the laminae is indurated in comparison with the host, indicating strong cementation by shallow groundwaters.

Microscopically, three different types of millimetre-scale laminae have been recognised. (1) Laminae of 3-8 mm thickness contain continuous layers of etched detrital grains (Fig. 4B) within a coarse mosaic of equigranular calcite crystals. Brown clays occur in patches amongst the grains, indicating an earlier clay matrix. Within the mosaic, bordering the detrital grains and in discontinuities there is commonly a network of filaments coated by micrite. (2) Irregular and discontinuous laminae $1-3 \mathrm{~mm}$ thick are grouped in layers $1-2 \mathrm{~cm}$ thick. Internally the laminae consist of dark micrite forming concentric coatings surrounding a central pore (Fig. 4C). In some cases the pore is lined by coarse calcite crystals about $15 \mu \mathrm{m}$ in diameter. These crystals follow a honeycomb-like pattern and are surrounded by laminated micrite. The morphology of the pores varies from spherical to tubular. (3) Fracture and brecciated micrite and micritic peloids may form some irregular laminae that occur bordering other types and are also typically a few millimetres thick. The majority of these laminae types show microstructures that have been considered to represent calcified root mats (Wright et al., 1988; Mack and James, 1992).

SEM images of these laminae show that the micrite is very porous. The micritic crystals are from 0.2 to $1 \mu \mathrm{m}$ across and their morphology varies from anhedral to subeuhedral. The pores are spherical and 1-4 $\mathrm{km}$ in diameter and are lined by micrite crystals. The pores occur throughout the micrite and may form clusters or be isolated (Fig. 4D,E). Micritic peloids of the third type of laminae are about 100 $\mu \mathrm{m}$ in diameter and carry irregular micritic coatings about $10 \mathrm{\mu m}$ thick. Rare filaments that are mostly non-calcified may be present in the micrite matrix and in the peloids. These are about $5 \mu \mathrm{m}$ wide and more than $200 \mu \mathrm{m}$ long. Some bifurcate (Fig. 4D) and show septae, indicating a probable fungal origin.

\subsection{Carbonate laminae in the Viñegra de Moraña area}

In this area the thickness of the paleosol profiles varies from 0.9 to $2 \mathrm{~m}$. These profiles developed on detrital sediments ranging from sandy clays to coarse arkosic sands that include clasts up to $8 \mathrm{~cm}$ in diameter. The bases of the profiles are typically gradational while the tops are sharp and commonly partially eroded with the surface overlain by a coarse arkose. The profiles show three horizons which are difficult to separate due to the gradational boundaries between them (Fig. 2). The lower horizon, about 40 $\mathrm{cm}$ thick, contains sparse carbonate nodules of about $3 \mathrm{~cm}$ in diameter. These are vertically elongated and occasionally coalesce to form a sharp planar top of the horizon. The intermediate horizon, about $1 \mathrm{~m}$ thick, contains horizontal carbonate laminae connected at different levels by vertical veins (Figs. 2 and 5A). The mean separation of horizontal laminae is about $20 \mathrm{~cm}$ at the base of the horizon and they become more closely spaced towards the top. The thickness of the laminae is $3-30 \mathrm{~mm}$ and they extend laterally for several metres. There is a direct relationship between the thickness of the laminae and host grain size, the coarser the grain size the thicker the laminae. Some elongated carbonate nodules up to $4 \mathrm{~cm}$ in diameter coalesce vertically to form composite nodules $25 \mathrm{~cm}$ long. The upper horizon is only preserved exceptionally as it is most often eroded. It has a mean thickness of $25 \mathrm{~cm}$ and consists 

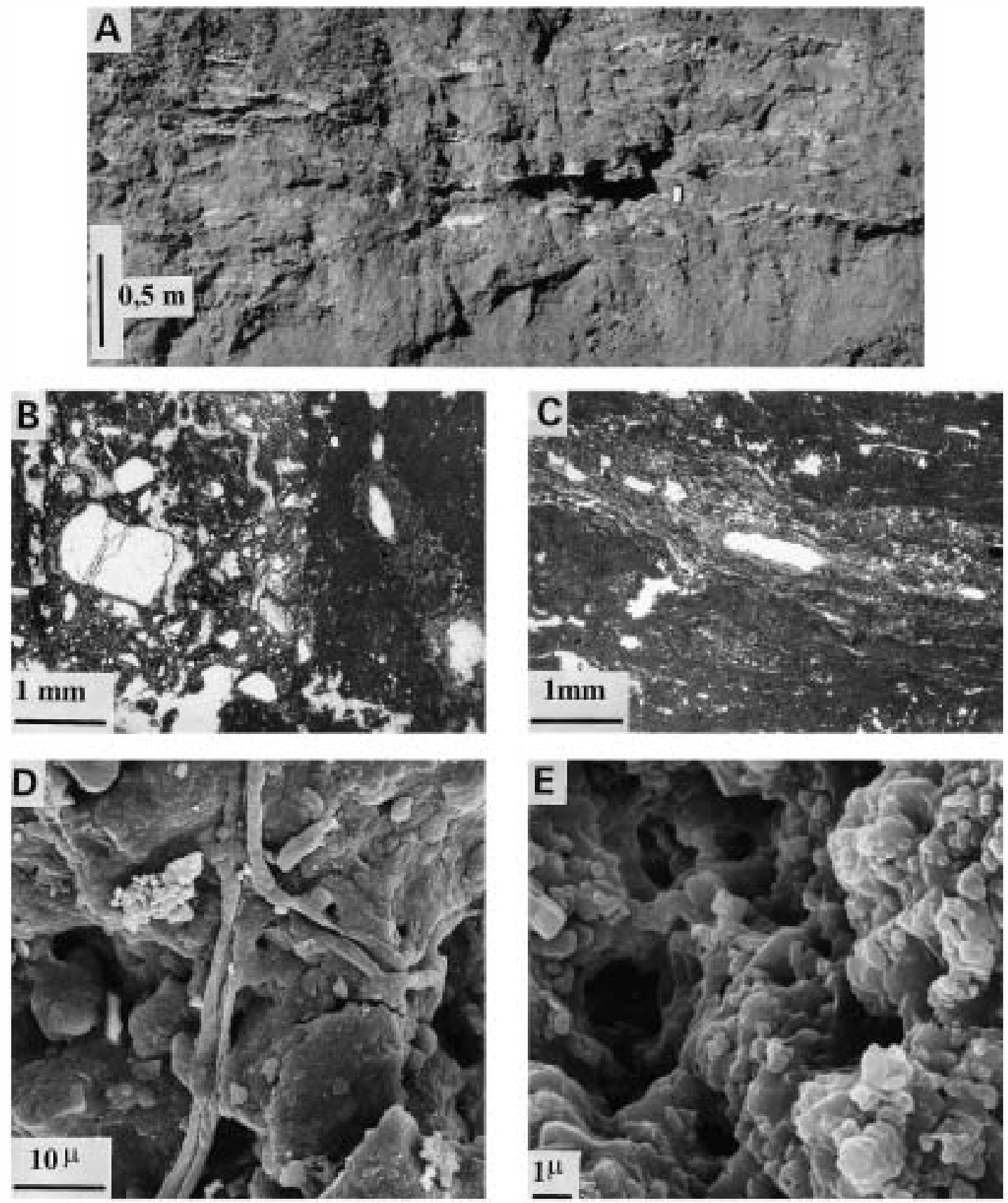

Fig. 4. Villacadima laminae. (A) Field view, the thin laminae occur between red detrital sandy clays. The laminae are very indurated. (B) Photomicrograph showing the microfabric of laminae formed by floating detrital grains etched and corroded by micritic and sparry carbonate. (C) Photomicrograph of root mats formed by laminated micrite around a central pore. (D) SEM image of non-calcified and bifurcating filament around a calcite crystal. (E) SEM view of the microporosity within the micritic mosaic. The pore may correspond to the cell protoplasts while the micrite may have formed by replacement of cell-walls and intracellular spaces by calcite. 

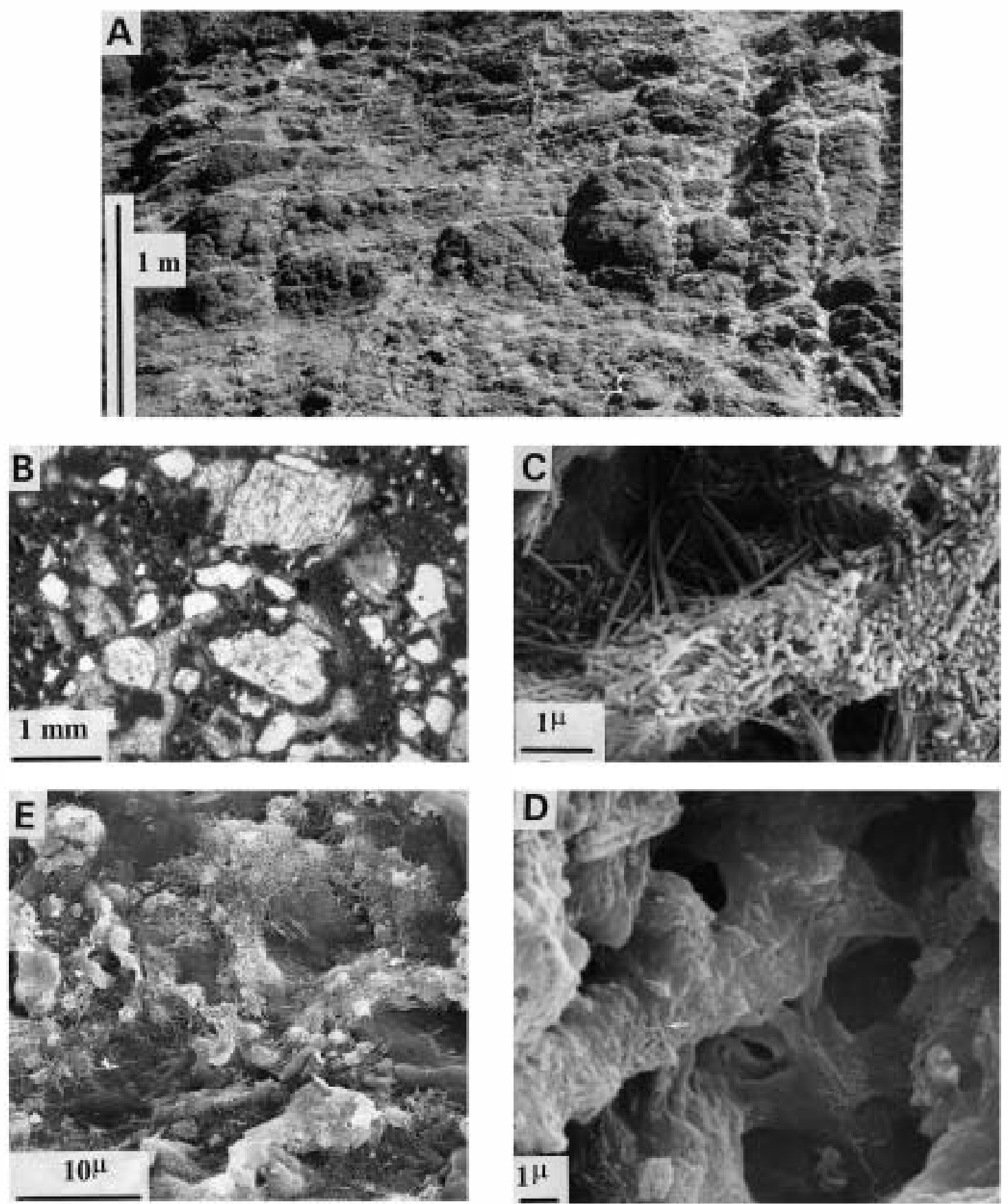

Fig. 5. Viñegra laminae. (A) Field view showing the network of horizontal and vertical carbonate laminae within coarse arkoses. (B) Photomicrograph of the fabric of the laminae composed of coarse detrital grains coated by micrite. Sparry calcite is also present. (C) SEM view of lamina consisting of needle-fibre calcite on a mucilaginous sheet. (D) SEM image of the mucilaginous sheets showing rounded pores partially coated by needle-fibre calcite (arrowed). (E) SEM view. Mucus sheet partially coated by masses of needles, areas without needles are more or less spherical. 
of a dense network of fine root tubes of about 1-2 mm wide and a few centimetres long.

The carbonate laminae of this profile are very soft and contain tubular pores that are the casts of root hairs. They consist of detrital grains from 5 to $80 \%$ embedded in a dense micrite. The micrite coats the detrital grain surfaces and enters within them through discontinuities, leading to the breakage of the grains. Grains of quartz, feldspar and rock fragments are corroded by the carbonate (Fig. 5B). Between the grains the micrite is generally homogeneous, but in some areas filaments and micrite tubes are present.

SEM images show that the laminae of the Viñegra de Moraña profile are very irregular and are in contact with the detrital grains. The laminae consist of masses of needle-like crystals ranging from a few micrometres to $30 \mu \mathrm{m}$ in length and about $1 \mu \mathrm{m}$ in diameter (Fig. 5C). The crystals lie at the surfaces of what are thought to have been mucilaginous areas (biofilms) that include spherical to tubular pores of about $4 \mu \mathrm{m}$ in diameter (Fig. 5D). Some filaments about $1 \mu \mathrm{m}$ in diameter and more than $10 \mu \mathrm{m}$ long project from these surfaces and are also coated by disorganised needle crystals. In some cases the mucilaginous sheets are coated by masses and balls of smaller needle crystals where the needle-crystal masses outline spherical to polyhedral areas on the sheets (Fig. 5E). The small needles that form these masses are considered to be microrods about $1 \mu \mathrm{m}$ long and $0.1 \mu \mathrm{m}$ wide. These lie on the surfaces of 'films' and form bridges connecting larger needle crystals. Needle crystals may vary in both morphologies and sizes, and both may reveal their origin. A detailed classification of needle calcite crystals has been published by Verrecchia and Verrecchia (1994). According to this classification, the needle crystals of the Viñegra de Moraña profile are of types M or MA, that is, monocrystals (M) or larger monocrystals rods occurring in multiples of two (MA). No serrate or polycrystalline forms have been recognised.

\section{Stable isotope geochemistry}

Laminae from the Viñegra and Villacadima areas have been selected for this study. The isotopic analyses were carried out on bulk samples and detrital grains may have contributed to the values obtained.

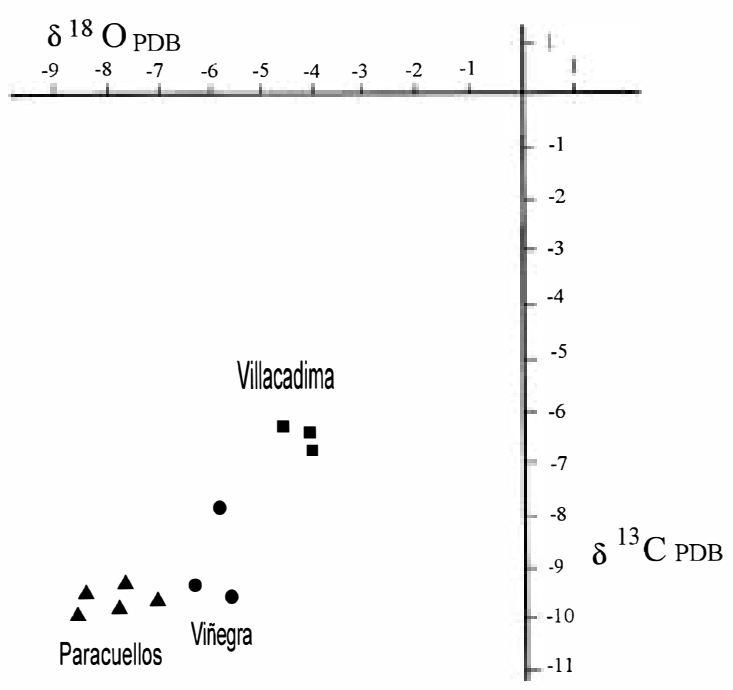

Fig. 6. $\delta^{13} \mathrm{C}-\delta^{18} \mathrm{O}$ cross-plot of the carbonate laminae of the three studied areas.

The Paracuellos data have been taken from a previous study (Alonso-Zarza et al., 1998a), but this paper only considers the calcitic laminae. The heavier isotopic values are from the Villacadima laminae (mean $\delta^{13} \mathrm{C}$ of $-6.5 \mathrm{PDB}$ and $\delta^{18} \mathrm{O}$ of $\left.-4.4 \mathrm{PDB}\right)$, whereas the lower values are from Paracuellos (mean $\delta^{13} \mathrm{C}$ of $-7.9 \mathrm{PDB}$ and $\delta^{18} \mathrm{O}$ of $-10.1 \mathrm{PDB}$ ) (Fig. 6). The Viñegra laminae show values very close to those of Paracuellos.

\section{Interpretation}

The three areas and profiles studied show similarities in the distribution and mesoscale morphology of the carbonate laminae, although there are significant differences in their internal structures and compositions. In the Paracuellos de Jarama area the arrangement of the crystals, their size, and morphology indicate that they are calcified root cells (Alonso-Zarza et al., 1998a). The cells are not totally calcified but mostly the cell-walls. The arrangement of the crystals within the laminae indicates that the inner parts of the root (medulla) are totally calcified; within the cells, the cell-walls are always calcified, whereas the cell protoplasts are only calcified in the medulla of the root, but not in the root cortices (Fig. 7) (see discussion in Alonso-Zarza et 


\begin{tabular}{|l|ccc|}
\hline $\begin{array}{l}\text { Location } \\
\text { Zones }\end{array}$ & Paracuellos & Villacadima & Viñegra \\
\hline $\begin{array}{l}\text { Root } \\
\text { Structure }\end{array}$ & Cortex & Cortex & $\begin{array}{l}\text { Mucilaginous } \\
\text { sheets in roots }\end{array}$ \\
$\begin{array}{l}\text { Cell } \\
\text { structure }\end{array}$ & $\begin{array}{l}\text { Calcification of } \\
\text { the whole cell }\end{array}$ & of cell-walls & $\begin{array}{c}\text { Calcification of } \\
\text { intracellular } \\
\text { spaces \& cell-walls }\end{array}$ \\
\hline
\end{tabular}

Fig. 7. Sketch of the different types of calcification in relation to the root structure. Black areas show the different scale porosity. The larger sketches represent in the three cases a sketch of a root section: $1=$ medulla, 2 = root cortex. In the Vinegra profile it is not possible to distinguish between medulla and root due to the poor preservation of the root microstructures.

al., 1998a), which contrasts with most occurrences of calcified roots where the cortical cells are preferentially calcified (Jaillard, 1987). Calcite crystals of this type have been referred to as Microcodium and regarded as typical features of rhizogenic calcretes such as those of the Aquitanian Basin, where Microcodium crystals may form up to $90 \%$ of the deposits (Wright et al., 1995). Here, most laminae consist of these calcified cells but they are absent from the rest of the calcrete profile. The arrangement and morphology of the crystals indicates an intraradicular and intracellular origin. The fact that calcification occurs in the medullas of the roots is important as it indicates that there is no need for the interplay of other organisms in the formation of crystals and laminae.

In the Villacadima profile the laminae show structures attributed to roots and root mats in which calcification is considered to be extracellular (Wright et al., 1995). The process of root calcification, and thus the formation of the laminae, is not fully understood. Some authors (Fedoroff et al., 1994) have recognised root pseudomorph fabrics in which the sclerenchyma is preserved while the parenchyma can be: (a) pre- served, in this case the cell walls are replaced by very small calcite crystals (less than $0.1 \mu \mathrm{m}$ ); (b) replaced by needles; and (c) replaced by a thin floating ring of micrite. The replacement is relatively fast (Wright et al., 1988). The morphology of the calcified root, very commonly showing a central pore and a coating of micrite, suggests that calcification took place in the cortex of the root and not in the medulla as in the Paracuellos profile. The micritic coatings can be interpreted in two ways: either calcification developed around fungal filaments coating the root, or, as indicated by Fedoroff et al. (1994), by replacement of the cell walls by calcite crystals. This second possibility explains the common occurrence of spherical pores within the micrite mosaic (Fig. 7), which may correspond to the protoplast of the cells while the micrite represents the calcified cell walls and intracellular spaces. The cells which are preferentially calcified are the cortical cells which contrast with the calcified medulla observed in the Paracuellos profile. However, the calcification of fungal filaments cannot be excluded as some filaments have been recognised under the SEM and micrite encrusted flaments are also found outside the root tube in places rich in 
detrital grains, coating, etching and even penetrating the grains.

In the Viñegra profiles the laminae are formed by detrital grains coated and embedded within micrite. The millimetre-scale carbonate-filled tubes recognised on the mesoscale reveal the activity of roots and root hairs, but this activity is not obvious on the microscale, where other structures such as biofihns, needle crystals and masses of needles or rods are common. These structures constitute the bulk of the laminae (Fig. 5C) and are responsible for most of the carbonate within them. Other types of carbonate precipitate such as equigranular micrite or coarse spar cement are very rare, and confirm the view that precipitation of the carbonate was biogenically induced. However, it is not easy to identity the organisms that caused the precipitation. Needle-fibre calcite crystals, similar to those recognised in the Vinegra profile, are a common feature of calcretes and other vadose settings where their origin may reflect purely physico-chemical processes (James, 1972; Rabenhorst and Wilding, 1986; amongst others). Commonly, however, an organic influence is invoked for their precipitation. Needle-fibre calcite is commonly associated with organic matrices of fungal origin (Calvet and Juliá, 1983; Callot et al., 1985; Phillips and Self, 1987). More precisely, Verrecchia and Verrecchia (1994) interpret MA rods as calcite precipitates in the interior of mycelium bundles. Another interesting aspect is the relationship of fungi with roots as in most cases the fungi form close to roots (Calvet and Juliá, 1983; Callot et al., 1985). The occurrence of root tubes and the mucilaginous sheets supporting the crystals (Fig. 7) confirm the biogenic-fungal origin of the needle crystals of the Viñegra de Moraña profile, and thus of the carbonate laminae. It is not possible to assess the exact place in the root where needle-fibre crystal formed. However, their location around pores of the biofihns or delineating spherical areas (Fig. 5D,E) may suggest an initial control by the morphology and size of the root cell-walls. The decomposition of the biofihns may lead to the disaggregation of the needle crystals and so some are randomly distributed along laminae and coating detrital grains.

Isotopic data (Fig. 6) show some variations between the different areas and types of laminae. In two cases, Paracuellos and Vinegra, the values are very low indicating the influence of organic carbon sourced from the soil organic matter (Wright and Alonso-Zarza, 1992) and the probable influence of light meteoric waters. In all of the Paracuellos de Jarama samples, and in two of the Viñegra samples the values of $\delta^{13} \mathrm{C}$ are very close to the absolute limit values for soil carbonates, of -12 to -13 PDB (Cerling, 1984; Bums and Rossinsky, 1989). These values are expected under the following conditions: $100 \%$ of $\mathrm{C}_{3}$ plants whose metabolism follow the Calvin pathway, no influence of heavier carbonate from pre-existing carbonates and lack of input of atmospheric $\mathrm{CO}_{2}$. Thus, these low isotopic values suggest that the soil carbonate was precipitated under a direct biological control within the soil, and this is clearly evident in the Paracuellos laminae where the root cells are calcified. The heavier values obtained from the Villacadima samples reveal the influence of detrital Mesozoic carbonate grains contained within the laminae, together with the possible influence of shallow groundwater that favoured the strong cementation of the laminae.

\section{Discussion}

The three examples described illustrate the importance of roots in the formation of carbonate laminae within soil profiles. In the study cases the soil profiles are poorly developed and it is difficult to classify them according to the morphological classifications of calcic soils (Gile et al., 1966; Machette, 1985). It is also difficult to determine if they are part of an $\mathrm{A}$ or B horizon of a soil as they may occur in different positions within the soil profiles or may not have any genetic relationship to other pedogenic horizons. Several terms have been proposed for horizons formed through the calcification of roots. Mack and James (1992) refer to them as Ak horizons as they occur in the uppermost horizon of a soil and contain carbonate, while Wright et al. (1995) refer to Krh horizons. In both cases the letter $\mathrm{K}$ is used to maintain the initial terminology of Gile et al. (1965) for strongly impregnated carbonate horizons. Most authors have described these laminae as calcified root mats. Any of the names for these horizons can be used to describe carbonate laminae formed by roots, the only problem is how to demonstrate their 
origin. This is not always very clear and, because root calcification can result in carbonate laminae with very different microstructures, laminae are not always easily attributable to roots.

\subsection{Organisms involved and timing of calcification in relation to root decay}

Our study shows that roots form laminae with three different microstructures which are controlled by the positions where the calcification occurs within the rhizosphere (Fig. 7) and by the other organisms involved. There may be a temporal control in relation to the life and death of the plant. In the Paracuellos de Jarama profiles calcification of the whole cell occurs in the medulla of the root while cell-walls are also calcified in the root cortex. This contrasts with most described cases of cell-root calcification, which typically occurs in cortical areas (Jaillard et al., 1991) but indicates that no other organisms were involved in calcification. Calcification was favoured by the use of $\mathrm{Ca}^{2+}$ in the cells to stabilise their walls (Clarkson, 1984; Kirkby and Pilbeam, 1984), so it could start when the root was still alive. It is difficult to identify the type of plant but the occurrence of silica spherulites in some cells may indicate a form similar to Graminea (Alonso-Zarza et al., 1998a). In Villacadima samples the laminae still preserve some details of the microstructure of the root. The central part corresponding to the medulla is missing, lacking any calcification, while the cortical areas are calcified (Fig. 7). This, together with the common occurrence of fungal filaments, may indicate a $M y$ corrhizae-type symbiotic association of roots and fungi. In this case the fungal hyphae are located in the external parts of the root and coat them. This is common among pine, oak and beech trees and even ferns, amongst others. The distribution of calcified and non-calcified areas may be linked to the relationship between the timing of the calcification process and the death of the root. Calcification of cell walls and intracellular space could have started in the fungal mycelium associated with the root, and caused that the symbiotic association stopped working, resulting in the death of the plant. When calcification was complete in the cortex of the root it could not progress inwards because the medulla had already decomposed and so there was no tissue left to calcify. In the Viñegra case, the roots are only preserved as small calcified tubes, but is difficult to appreciate on a microscale where only evidence of fungal activity has been recognised. This activity could have developed with the decay of the root.

One more question remaining is whether only one type of plant is involved in the process or different plants can form laminae. In only one case there is evidence that Gramine may be involved. Elsewhere the microstructure of the laminae does not give any indication of the type of plant. Palynological data (Munuera and Carrión, 1991) from areas close to places where well developed Pleistocene calcretes occur in SE Spain suggest that thick laminar calcrete profiles are related to areas of growth Chenopodiacea and Artemisia (Alonso-Zarza et al., 1998b), whereas Pliocene calcrete profiles from the Madrid Basin seem to be related to the roots of pines (Wright et al., 1998). In short, it seems that different plants can form root mats whose activity results in the formation of carbonate laminae, either isolated within detrital sediments or amalgamated and forming thick calcrete profiles. The fact that roots form mats instead of vertical root systems seems to be more a strategy to obtain more water in a porous sediment than a requirement of a precise type of plant.

\subsection{Formation of the laminae within the soil}

The detailed study of these thin laminae allows a new approach to the understanding of laminar calcrete formation, either within thick calcrete profiles or within detrital sediments that did not undergo strong pedogenic modification. The fact that root activity is the main process controlling their formation clearly indicates that laminae must have formed within the sediment or soil where plants were forming a root mat. Disruption of the sediment is demonstrated by etching and breaking of the detrital grains and clay matrices. The growth of carbonate displaced and replaced the host sediment. No evidence of water bodies on the surface of the sediment has been recognised, either bioclasts or spherulites, which are relatively common in thick laminar calcrete profiles (Wright et al., 1996) and may form in desiccating surficial ponded waters (Verrecchia et al., 1995). Formation of horizontal laminae or root mats is controlled by the supply of water. Plants may obtain 
water from very surficial water tables (Cohen, 1982; Mack and James, 1992), while wide and horizontal root systems allow them to obtain the maximum quantities of the scarce vadose water retained in the sediment. The location of the water table was controlled by the aggradational regime of the distal fan areas, that worked in the same way as that in fluvial floodplains of aggradational river systems where every new input of sediment is accompanied by a rise in the water table.

The arrival of new sediment on the vegetation cover that was forming the laminae may have caused the death and burial of the plants. Thus, the formation of calcified root mats or carbonate laminae intercalated within detrital sediments indicates relatively short periods of no sedimentation and stabilisation, in which the laminae formed, followed by rapid events of sedimentation. Longer stabilisation periods account for the formation of thicker laminar calcrete (Watts, 1980; Machette, 1985; Sancho and Meléndez, 1992; Sanz, 1996), although erosion and sedimentation can also contribute to their formation (Sanz and Wright, 1994; Alonso-Zarza et al., 1998b). Erosion or high sedimentation rates will inhibit both lamina formation and preservation. From this point of view thin carbonate laminae can be used as indicators of depositional environments with periods of relative stability that allowed the installation of a vegetation cover, followed by events of sedimentation. These conditions are common in distal areas of alluvial fans and within floodplains. Relatively porous host sediments such as sands or sandy siltstones will be the preferred sites for the formation of the laminae, that are envisaged as the initial stages of formation of the thick laminar calcrete profiles.

\section{Conclusions}

Carbonate laminae in the three paleosol profiles examined are similar in terms of the distribution and morphology. The laminae represent calcified root mats and their micromorphology and structure depend on the position in which calcification occurs in the rhizosphere, on the organisms involved, and on whether the plant was alive or dead when calcification occurred. In the Paracuellos laminae the preservation of the microstructure of the root cells indicates that calcification could have started when the plant was alive and needed $\mathrm{Ca}^{2+}$ to stabilise its cell-walls. There is no evidence of other organisms contributing to calcification. In the Villacadima laminae consist of laminated micrite surrounding a central pore. The pore represents the medulla of the root while the laminated micrite formed through the replacement of cell-walls and intracellular spaces by micrite crystals. Microstructures indicate the interplay of roots and fumgi and calcification started while the plant was still alive. By contrast, the lack of preservation of the detailed root microstructures in the Viñegra de Moraña profile suggest that formation of the laminae occurred shortly after the decay of the root.

The arrangement of the laminae within the profiles indicates that their formation occurred in relation to the buried part of the plant and not in direct contact with the atmosphere. The low pedogenic weathering of the host sediments indicates poorly developed soils in which pedogenesis is mostly reflected in the formation of the laminae. These laminae formed when sedimentation was relatively low and episodic, so that after each new sediment input the root system occupied progressively higher surfaces, resulting in the formation of carbonate laminae separated by clastic sediments. If the sedimentation rate is very low laminae will be superimposed allowing the development of thicker and harder rhizogenic calcretes or rootcretes.

\section{Acknowledgements}

The author wishes to thank J.P. Calvo, P.G. Silva and M. Martín for discussions and assistance with field work. SEM analysis was carried out in CMEUCM. This work was presented at the Workshop on 'Microbial influence on carbonate diagenesis' celebrated in September 1997 in Chichiliane (France) and I want to thank Drs. Camoin and Arnoud for organising such a nice meeting and creating a warm and enthusiastic microbial atmosphere as well as for the editorial work. The paper has benefited from review by Dr. Braithwaite. The work has been partially supported by DGICYT through project PB-95 0114. 


\section{References}

Alonso, A.M., Calvo, J.P., García del Cura, M.A., 1986. Sedimentologia y petrología de los abanicos aluviales y facies adyacentes en el Neógeno de Paracuellos de Jarama (Madrid). Estudios Geol. 42, 79-101.

Alonso-Zarza, A.M., Wright, V.P., Calvo, J.P., García del Cura, M.A., 1992. Soil-landscape and climatic relationships in the Middle Miocene of the Madrid Basin. Sedjmentology 39, 17 35.

Alonso-Zarza, A.M., Sanz, M.E., Calvo, J.P., Estévez, P., 1998a. Calcified root cells in Miocene pedogenic carbonates of the Madrid Basin: evidence for the origin of Microcodium b. Sediment. Geol. 116, 81-97.

Alonso-Zarza, A.M., Silva, P., Goy, J.L., Zazo, C., 1998b. Fansurface dynamics and biogenic calcrete development: Interactions during ultimate phases of fan evolution in the semiarid SE Spain (Murcia). Geomorphology 24, 147-167

Burns, S.J., Rossinsky Jr., V., 1989. Late Pleistocene mixing zone dolomitization, southeastern Barbados. West Indies. Discussion. Sedimentology 36, 1135-1142.

Callot, G., Mousain, D., Plassard, C., 1985. Concentrations de carbonate de calcium sur les parois des hyphes mycéliens. Agronomie 5, 143-150.

Calvet, F., Juliá, R., 1983. Pisoids in the caliche profiles of Tarragona (NE Spain). In: Peryt, T.M. (Ed.), Coated Grains. Springer, Berlin, pp. 73-79

Calvo, J.P., Alonso-Zarza, A.M., García del Cura, M.A., Ordoñez, S., Rodriguez-Aranda, J.P., Sanz, M.E., 1996. Sedimentary evolution of lake systems through the Miocene of the Madrid Basin: paleoclimatic and paleohydrological constraints. In: Friend, P.F., Dabrio, C.J. (Eds.), Tertiary Basins of Spain: the Stratigraphic Record of Crustal Kinematics. Cambridge University Press, Cambridge, pp. 272-277

Cerling, T.E., 1984. The stable isotope composition of modern soil carbonate and its relationships to climate. Earth Planet. Sci. Lett. 71, 229-240.

Clarkson, D.T., 1984. Calcium ransport between tissues and its distribution in the plant. Plant, Cell Environ. 7, 449-456.

Cohen, A.S., 1982. Paleoenvironments of root cast from the Koobi-Fora Formation, Kenya. J. Sediment. Petrol. 52, $401-$ 414.

Esteban. M., Klappa, C.F., 1983. Subaerial exposure environments. In: Scholle, P.A., Bebout, D.G., Moore, C.H. (Eds.), Carbonate Depositional Environments. Am. Assoc. Per. Geol. Mem. 33, 1-96.

Fedoroff, N., Country, M.A., Lacroix, E., Oleschko, K., 1994. Calcitic accretion on indurated volcanic materials (example of tepetates, Altiplano, Mexico). Proc. XVth World Congress, Soil Sci., Acapulco, Vol. 6A, pp. 459-472

Gile, L.H., Peterson, F.F., Grossman, R.B., 1965. The K horizon: a master horizon of carbonate accumulation. Soil Sci. 97, 7482.

Gile, L.H., Peterson, F.F., Grossman. R.B., 1966. Morphological and genetic sequences of carbonate accumulation in desert soils. Soil Sci. 101, 347-360.
IGME, 1980. Mapa Geológico de España. E: 1:50.000. Hoja 15-19. Fontiveros. Instituto Geológico de España, Madrid.

Jaillard, B., 1987. Les structures rhizomorphes calcaires: modèle de rèorganisation des minéraux du sol par les racines. Thesis, Institut National de la Recherche Agronomique, Laboratoire de Science du Sol, Montpellier, $228 \mathrm{pp}$.

Jaillard, B., Guyon, A., Maurin, A.F., 1991. Structure and composition of calcified roots, and their identification in calcareous soils. Geoderma 50, 197-210.

James, N.P., 1972. Holocene and Pleistocene crust (caliche) profiles. Criteria for subaerial exposure. J. Sediment. Perol. $42,817-836$.

Jones, B., 1992. Constuction of spar calcite crystals around spores. J. Sediment. Petrol. 62, 1054-1057

Junco, F., Calvo, J.P., 1983. Cuenca de Madrid. In: Libro Jubilar J.M. Ríos, 2, Instuto Geológico y Minero de España, Madrid, pp. $534-543$.

Kirkby, EA., Pilbeam, D.J., 1984. Calcium as a plant nutrient. Plant, Cell Environ. 7, 397-405

Machette, N.L., 1985. Calcic soils of the southwestem United States. Geol. Surv. Am. Spec. Publ. 203, 1-21

Mack, G.H., James, W.C., 1992. Calcic paleosols of the PlioPleistocene Camp Rice and Palomas Formation, southern Rio Grande rift, USA. Sediment. Geol. 77, 89-109.

Munuera, M., Carrión, S.J., 1991. Palinología de un depósito arqueológico en el sureste ibérico semiánido: Cueva del Algarrobo (Mazarrón, Múrcia). Cuat. Geomorfol. 5, 107-118.

Phillips, S.E., Self, P.G., 1987. Morphology, crystallography and origin of needle-fibre calcite in Quatemary pedogenic calcretes of South Australia. Aust. J. Soil Res. 25, 429-444.

Portero, J.M., Olivé, A., 1983. E1 Terciario del Borde Meridional del Guadarrama y Somosierra. In: Libro Jubilar J.M. Ríos, 2, Instituto Geológico y Minero de España, Madrid, pp. 527534.

Rabenhorst, J.A., Wilding, P.E., 1986. Pedogenesis on the Edwards Plateau Texas, III. New model for the formation of petrocalcic horizons. Soil Sci. Soc. Am. J. 50, 693-699.

Sancho, C., Meléndez, A., 1992. Génesis y significado ambiental de los caliches Pleistocenos de la región del Cinca (Depresión del Ebro). Rev. Soc. Geol. Esp. 5, 81-93.

Santisteban, J.I., Mediavilla, R., Martín-Serrano, A., Dabrio, C.J., 1996. The Duero Basin: a general overview. In: Friend, P.F., Dabrio, C.J. (Eds.), Tertiary Basins of Spain: The Stratigraphic Record of Crustal Kinematics. Cambridge University Press, Cambridge, pp. 183-187.

Sanz, M.E., 1996. Sedimentología de las formaciones Neógenas del sur de la Cuenca de Madrid. Monografías. Ministerio de Fomento, CEDEX, Madrid, 245 pp.

Sanz, M.E., Wright, V.P., 1994. Modelo alternativo para el desarrollo de calcretas: un ejemplo del Plio-Cuatemario de la Cuenca de Madrid. Geogaceta 16, 116-119.

Tate, T.A., Retallack, G.J., 1995. Thin sections of paleosols. J. Sediment. Res. A65, 579-580.

Verrecchia, E.P., Verrecchia, K.E., 1994. Needle-fiber calcite: a critical review and a proposed classification. J. Sediment. Res. A64, 650-664.

Verrecchia, E.P., Freytet, P., Verrecchia, K.E., Dumont, J.L., 
1995. Spherulites in calcrete laminar crusts: biogenic $\mathrm{CaCO}_{3}$ precipitation as a major contributor to crust formation. J. Sediment. Res. A65, 690-700.

Verrecchia, E.P., Freytet, P., Verrecchia, K.E., Dumont, J.L., 1996. Spherulites in calcrete laminar crus $\mathbf{s}$ : biogenic $\mathrm{CaCO}_{3}$ precipitation as a major contributor to crust formation. Reply. J. Sediment. Res. 66, 1041-1044.

Watts, N.L., 1980. Quatemary pedogenetic calcretes from the Kalahari, mineralogy, genesis and diagenesis. Sedjmentology 27, 661-687.

Wright, V.P., Alonso-Zarza, A.M., 1992. Significado de la composición isotópica $\left(\delta^{13} \mathrm{C}\right.$ y $\left.\delta^{18}\right)$ en paleosuelos carbonatados. Mioceno de la Cuenca de Madrid. Geogaceta 11, 61-63.

Wright, V.P., Platt, N.H., Wimbledon, W., 1988. Biogenic laminar calcretes: evidence of calcified root mat horizons in pale- osols. Sedimentology 35, 603-620.

Wright, V.P., Platt, N.H., Marriot, S.B., Beck, V.H., 1995. A classification of rhizogenic (root-formed) calcretes, with examples from the Upper Jurassic-Lower Carboniferous of Spain and Upper Cretaceous of southern France. Sediment. Geol. 100, $143-158$

Wright, V.P., Beck, V.H., Sanz-Montero, M.E., 1996. Spherulites in calcrete laminar crusts: biogenic $\mathrm{CaCO}_{3}$ precipitation as a major contributor to crust formation. Discussion. J. Sediment. Res. 66, 1040-1041.

Wright, V.P., Sanz, M.E., Beck, V.H., 1998. Rhizogenic origin for laminar-platy calcretes, Plioquatemary of Spain. In: Cañaveras, J.C., García del Cura, M.A., Soria, J. (Eds.), Sedimentology at the Dawn of the Third Millennium. Publicaciones de la Universidad de Alicante, p. 826. 